\title{
Starch hydrolyzing enzyme production from Aspergillus niger EFRL-FC-024 using molasses as carbon source
}

Muhammad Asif Jokhio ${ }^{1,2 *}$, Habib Ahmed Naqvi ${ }^{1}$, Aneela Yasmin ${ }^{2}$, Najeebullah Channa ${ }^{3}$, Abdul Sattar Qureshi ${ }^{1}$ and Imrana Khushk ${ }^{1}$

1. Institute of Biotechnology and Genetic Engineering, University of Sindh, Jamshoro-Pakistan

2. Department of Biotechnology, Sindh Agriculture University, Tandojam-Pakistan

3. Institute of Environmental Engineering \& Management Mehran University of Engineering and TechnologyPakistan

*Corresponding author's email: asifjokhio51@yahoo.com

Citation

Muhammad Asif Jokhio, Habib Ahmed Naqvi, Aneela Yasmin, Najeebullah Channa, Abdul Sattar Qureshi and Imrana Khushk. Starch hydrolyzing enzyme production from Aspergillus niger EFRL-FC-024 using molasses as carbon source. Pure and Applied Biology. Vol. 10, Issue 1, pp262-271.

http://dx.doi.org/10.19045/bspab.2021.100027

Received: 23/06/2020 Revised: 24/08/2020

Accepted: 01/09/2020

Online First: 17/09/2020

\section{Abstract}

Amylase is one of the important industrial enzyme due to its application in detergents, food and textile industries. In present study, the production of amylase, a starch hydrolyzing enzyme, was optimized using Aspergillus niger strain EFRL-FC-024 under various conditions i.e. incubation time, carbon source, $\mathrm{pH}$ and temperature. Amylase production was recorded as $2.26 \mathrm{U} / \mathrm{mL}$ after $96 \mathrm{~h}$ of incubation in mineral medium containing glucose as carbon source. In contrast its concentration increased to $2.55 \mathrm{U} / \mathrm{mL}$ when molasses was added to mineral medium. However, the highest enzymes titer of $2.97 \mathrm{U} / \mathrm{mL}$ was achieved in optimized conditions $(1.0 \% \mathrm{w} / \mathrm{v}$ molasses, $96 \mathrm{~h}, \mathrm{pH} 6.0$ and temperature $40^{\circ} \mathrm{C}$ ). Molasses are a cost-effective carbon source for amylase production using Aspergillus niger strain EFRL-FC-024. Thus this enzyme can be produced cost effectively using low cost agro-industrial waste natively like molasses and could be utilized in detergent or textile industry or even for the saccharification of starchy materials i.e. potato waste to produce ethanol and other commodity products.

Keywords: Amylase; Aspergillus niger EFRL-FC-24; Molasses; Starch hydrolyzing Introduction

Amylase (EC:3.2.1.1) hydrolyzes starch to release glucose, maltose and dextrose [1-4]. It is utilized in food, detergent, paper, textile and pharmaceutical industries. It also plays an important role in cereal processing, baking, sweetener, syrup and beverages production in the food industry [5-12]. The annual sales of amylase, in the global market, are estimated to be $\$ 11$ million [10]. In 2015 the enzyme's market was $\$ 8.18$ billion and it is estimated that this market will reach to $\$ 17.50$ billion in 2024 , globally [11]. Increasing demands of amylase have influenced local researchers to optimize amylase production using local inexpensive materials and novel strains $[12,13]$. Based on the cleavage sites in starch, amylases have been categorized into three groups. $\alpha$ amylase hydrolyze $\alpha, 1-4$ glucosidic linkage, 
$\beta$-amylase cleave $\alpha$ 1-4 glucosidic linkage and glucoamylase cleaves $\alpha, 1-4$, and 1-6 linkage releasing single glucose units [14]. Amylase can be obtained from microbes, plants and animals. However fungal and bacterial amylase are more promising due to less time required for their production, huge diversity, and low production costs $[15,16]$. Amylase could be produced through solidstate and submerged fermentation conditions [17]. However, submerged fermentation is routinely used for amylase production [16, 18]. It is advantageous because it provides a better growth environment to microbes, less contamination chances, easy process control, high productive yield, is less labor-intensive, and cost-effective [15]. Keeping in view the increasing demands of amylase a local fungal strain was used for the production of starch hydrolyzing enzyme and process conditions were optimized. Enzyme produced from this study could be utilized for the saccharification of starchy materials like potato waste etc. to produce ethanol and other commodity products. Further applications include use in detergent and textile industry in Pakistan.

\section{Materials and Methods Inoculum preparation}

Aspergillus niger strain EFRL-FC-024 (A. niger) was obtained from Enzyme and Fermentation Research Laboratory at the Institute of Biotechnology and Genetic Engineering (IBGE), University of Sindh, Jamshoro. The culture was activated on synthetic medium containing $20 \mathrm{~g} / \mathrm{L}$ of dextrose, $20 \mathrm{~g} / \mathrm{L}$ of agar, $10 \mathrm{~g} / \mathrm{L}$ of peptone and incubated at $37{ }^{\circ} \mathrm{C}$ for 7 days then subcultured on fresh glucose agar medium. Culture was grown for 7 days to obtain luxurious growth that was used as inoculum in all fermentation experiments. For the preparation of spore suspension, the surface of culture stock of $A$. niger was slightly scrubbed with a wire loop and $10 \mathrm{~mL}$ of sterilized water was added. $1.0 \%$ v/v culture was inoculated in fermentation media [19].

\section{Culture conditions amylase production}

The fermentation medium was composed of glucose $20 \mathrm{~g} / \mathrm{L}$, Peptone $10 \mathrm{~g} / \mathrm{L}, \mathrm{CaCl}_{2}$. $2 \mathrm{H}_{2} \mathrm{O} 1 \mathrm{~g} / \mathrm{L}, \mathrm{KH}_{2} \mathrm{PO}_{4} 1 \mathrm{~g} / \mathrm{L}, \mathrm{MgSO}_{4} .7 \mathrm{H}_{2} \mathrm{O}$ $1.0 \mathrm{~g} / \mathrm{L}, \mathrm{MnCl}_{2} .2 \mathrm{H}_{2} \mathrm{O} 0.5 \mathrm{~g} / \mathrm{L}, \mathrm{NH}_{4} \mathrm{NO}_{3} 1$ $\mathrm{g} / \mathrm{L}$. Fermentation medium composition was slightly modified according to the earlier reports [19]. This medium was used for amylase production. All chemicals were purchased from Sigma and/ or E. Merck. Molasses was collected from "Mehran Sugar Mill, Tando Allahyar". The $\mathrm{pH}$ of the medium was adjusted to 6.0 using 1N HCL or $1 \mathrm{~N} \mathrm{NaOH}$. The medium was inoculated with fresh $A$. niger, fungal culture and incubated at $37^{\circ} \mathrm{C}$ for $144 \mathrm{~h}$.

\section{Fermentation process of amylase}

$50 \mathrm{~mL}$ of sterilized fermentation medium in a $250 \mathrm{~mL}$ conical flask was inoculated with $2.0 \% \mathrm{v} / \mathrm{v}$ of spore suspension. The flask was incubated at $37^{\circ} \mathrm{C}$ without shaking. After an interval of $24 \mathrm{~h}$ as incubation time, the culture was filtered through Whatman filter paper (No.1) to remove biomass. The harvested biomass was dried out at $80^{\circ} \mathrm{C}$ and weighed in $\mathrm{g} / 50 \mathrm{~mL}$.

\section{Optimization of fermentation conditions}

Different sugars (glucose, molasses, sucrose, fructose, maltose, galactose and mannitol) were used as carbon sources to evaluate their effect on amylase production. The fermentation medium was supplemented with different sugars accordingly and flasks were incubated at $37^{\circ} \mathrm{C}$ for $144 \mathrm{~h}$. Different parameters like effects of incubation time (24-144 h), $\mathrm{pH}$ (4-9) and temperature (20 to $60^{\circ} \mathrm{C}$ ) were optimized for amylase production by $A$. niger under submerged condition. Further, final $\mathrm{pH}$ of the broth culture was determined by $\mathrm{pH}$ meter (Scientific Instrument). The culture broth was used for the determination of total protein, total sugar, reducing sugar and amylase activity. 
Determination of amylase activity, total protein, reducing sugar and total sugar

Amylase activity was tested either by Shafique or Fischer and Stein method [20]. $1 \mathrm{~mL}$ of culture broth, $1 \mathrm{~mL}$ of substrate $(1 \%$ w/v soluble starch) was added and kept in water bath for $15 \mathrm{~min}$ at $37^{\circ} \mathrm{C}$. Then $2 \mathrm{~mL}$ of 3, 5 dinitro- salicylic acid (DNS) reagent was added and the reaction was stopped by putting tubes in boiling water bath at $100^{\circ} \mathrm{C}$ for $5 \mathrm{~min}$. Then the reaction was cooled to room temperature, the absorbance was recorded by Spectrophotometer at $540 \mathrm{~nm}$ against the blank. Blanks were prepared by replacing culture broth and substrate with water. One unit of amylase activity is defined as the amount of enzyme required to release 1 micromole of reducing sugar under assay conditions.

Total protein was analyzed according to the Lowery et al. (1951) method using bovine serum albumin as standard [21]. Total sugar was determined according to Montgomery (1961) method using glucose as a standard [22]. Reducing sugar was measured according to Miller et al. (1959) method using glucose as standard [23].

Results Effect of time of incubation on production of amylase
In present study, amylase production was recorded from 24 to $144 \mathrm{~h}$ using $A$. niger strain EFRL-FC-024. Amylase concentration increased with increase in fermentation time and maximum amylase activity of $2.26 \mathrm{U} / \mathrm{mL}$ was observed at $96 \mathrm{~h}$ when the culture was grown on glucose mineral medium, pH 6.0 and incubated at 37 ${ }^{\circ} \mathrm{C}$. Results are depicted in (Fig. 1). Results suggest that the enzyme was produced in log phase to early stationary phase. More than $50 \%$ of enzyme activity decreased after 144 $\mathrm{h}$ of incubation. Highest total protein content was reached to $0.50 \mathrm{mg} / \mathrm{mL}$ at $48 \mathrm{~h}$ of incubation period. Microbial growth was also monitored from 24 to 144 h. Highest biomass was noted at the $4^{\text {th }}$ day of incubation however, and then declined with increasing incubation period.

Residual total and reducing sugar during fermentation was observed from 24 to $144 \mathrm{~h}$. The maximum total sugar was noted 1.92 $\mathrm{mg} / \mathrm{mL}$ at $24 \mathrm{~h}$ and the lowest amount of total sugar was recorded after $144 \mathrm{~h}$. The highest reducing sugar was also detected at $24 \mathrm{~h}$ of fermentation time $0.88 \mathrm{mg} / \mathrm{mL}$ then declined with incubation time. These results suggest that sugar was consumed by microorganisms for its growth and enzyme production. Results are shown in (Fig. 2).

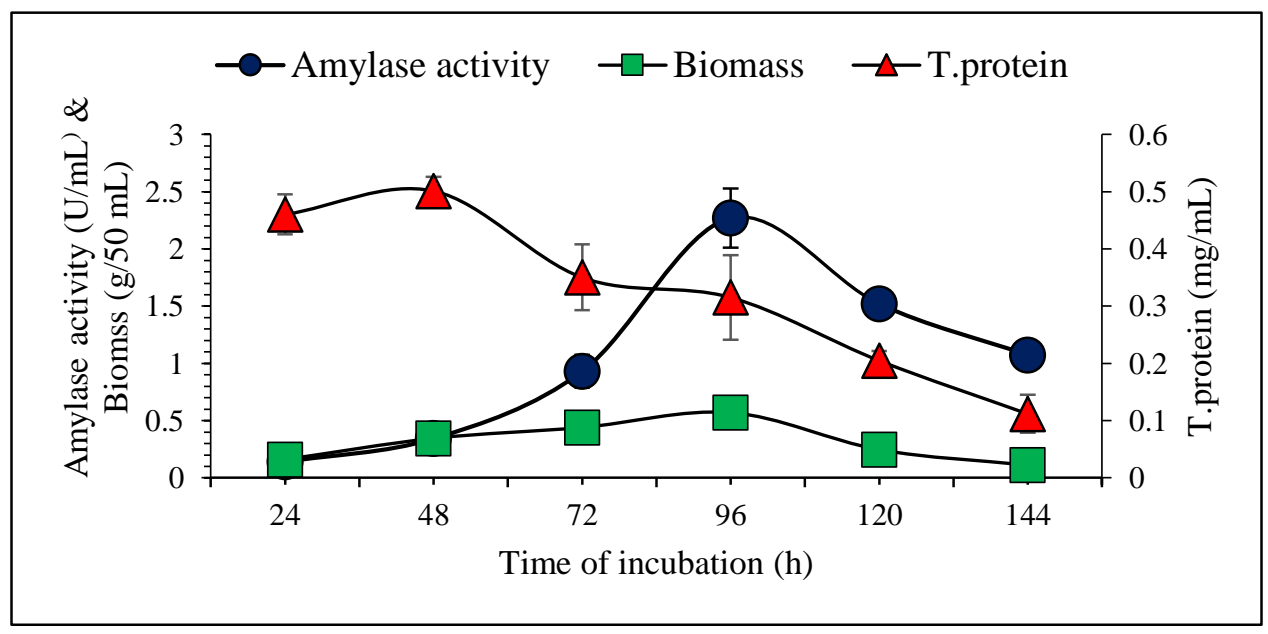

Figure 1. Effect of time of incubation on microbial growth and $\alpha$-amylase production 


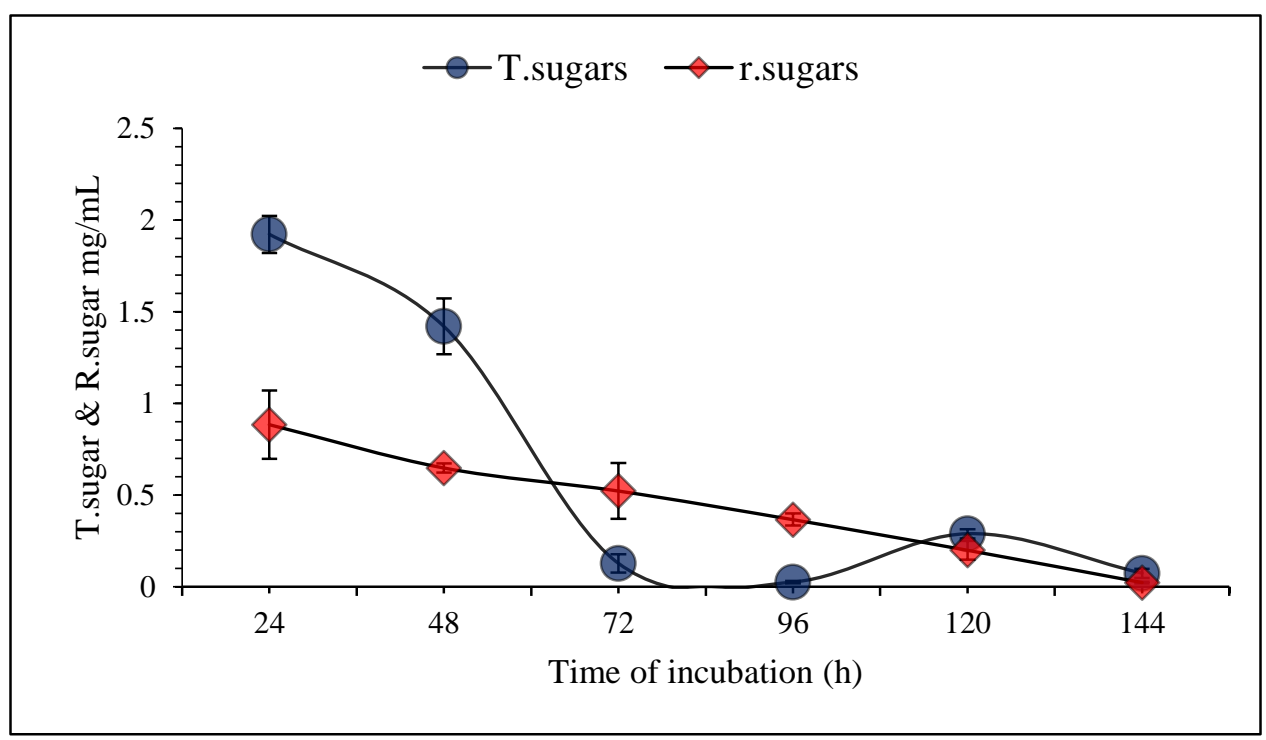

Figure 2. Residual total and reducing sugars at different fermentation time

Effect of carbon source on amylase production

Effect of different carbon sources (glucose, molasses, sucrose, fructose, maltose, galactose and mannitol) was tested on amylase production in mineral medium. Glucose was replaced with molasses, fructose, sucrose, maltose, galactose and mannitol at $1 \% \mathrm{w} / \mathrm{v}$ in fermentation medium for amylase synthesis and cell growth. Maximum amylase production was achieved in molasses mineral medium $(2.55 \mathrm{U} / \mathrm{mL})$ as compared to other sugars. Molasses is an industrial waste that contains sugars, nitrogen compounds, vitamins and minerals that support microbial growth and enzyme production. The highest amount of total protein was recorded in molasses fermented medium $(0.93 \mathrm{mg} / \mathrm{mL})$ at $96 \mathrm{~h}$. Results are depicted in (Fig. 3). Different carbohydrates $(1 \% \mathrm{w} / \mathrm{v})$ were incorporated in the fermentation medium. Residual total and reducing sugars were measured after $96 \mathrm{~h}$. Maximum amount of total and reducing sugars were $(4.11 \mathrm{mg} / \mathrm{mL})$ and $(2.25 \mathrm{mg} /$ $\mathrm{mL}$ ), respectively, in molasses fermented medium as compared to all other tested sugars. Results are displayed in (Fig. 4).

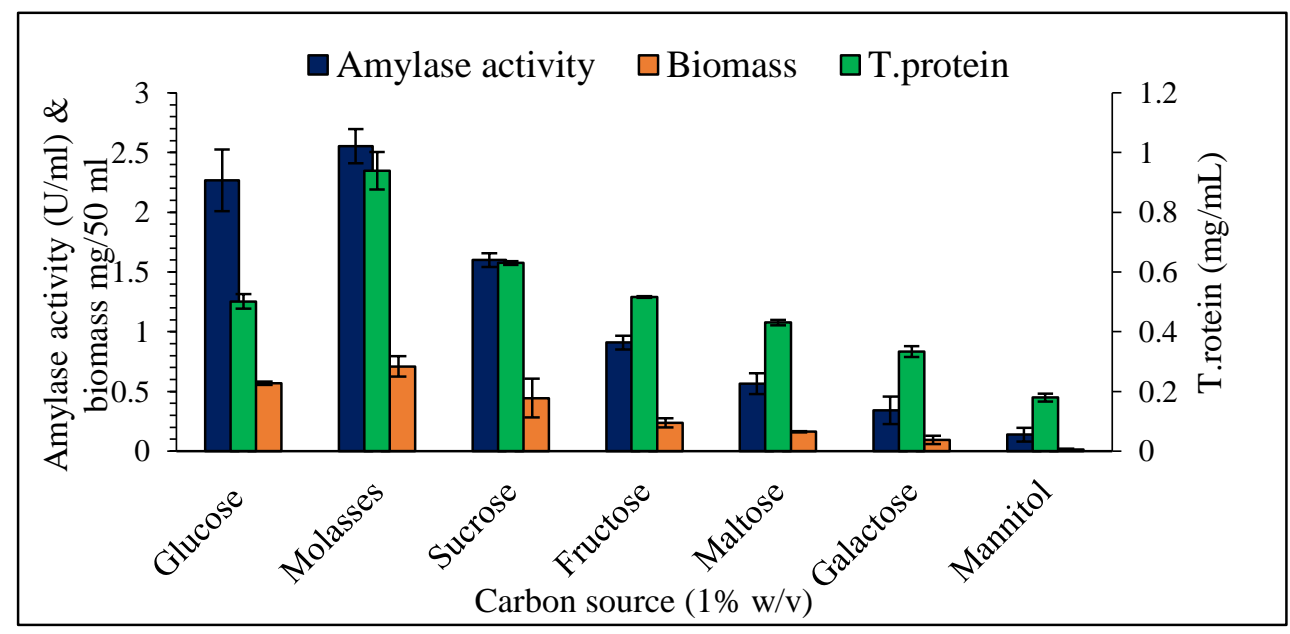

Figure 3. Effect of 1\% carbon sources on production of amylase by Aspergillus niger 


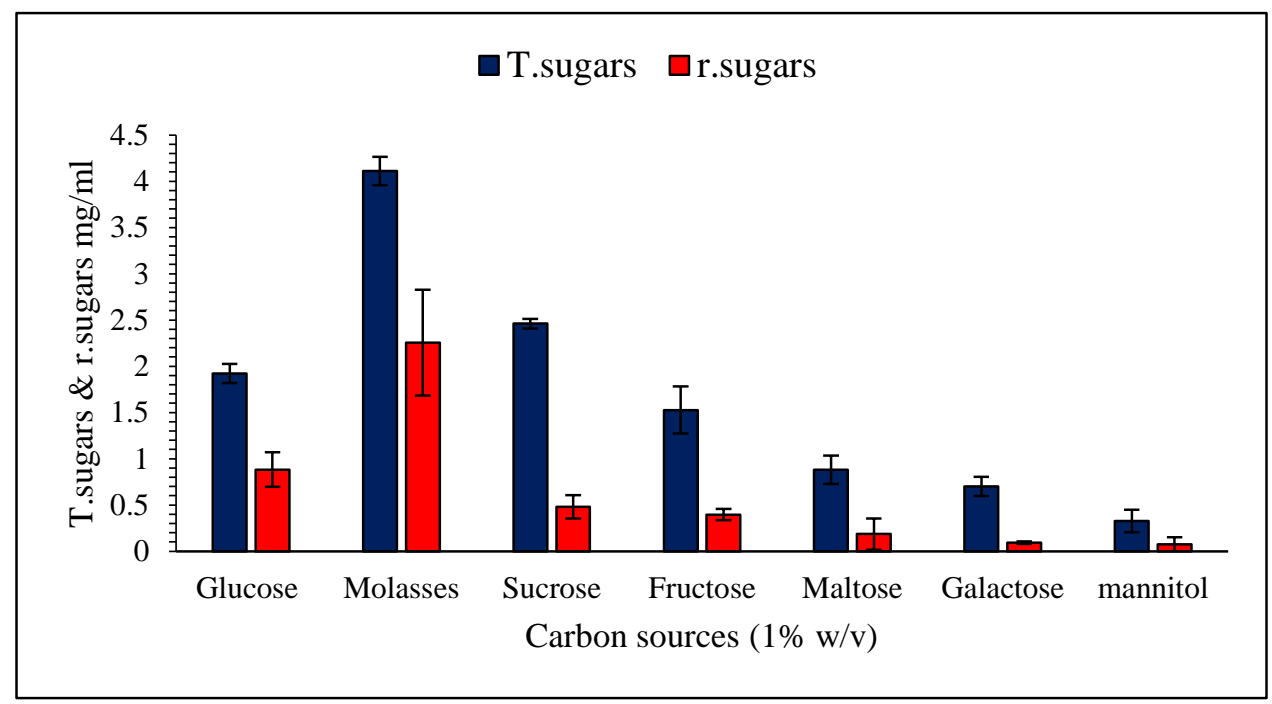

Figure 4. Residual total and reducing sugars from culture broth by Aspergillus niger

Effect of $\mathrm{pH}$ on the production of amylase Initial $\mathrm{pH}$ is one of the important parameter responsible for certain changes in the enzyme activity and growth of organism. In current study, a range of $\mathrm{pH}(4-9)$ was analyzed to record its influence on amylase production. Results showed that the highest enzyme activity of $2.63 \mathrm{U} / \mathrm{mL}$ was achieved at $\mathrm{pH}$ 6.0. Further increase in the $\mathrm{pH}$ declined the enzyme titers. The minimum activity of amylase was noted at $\mathrm{pH}$ 9.0. Results are indicating that the amylase production was highest when the strain was grown in the acidic $\mathrm{pH}$ range. During fermentation, culture medium was tested for the total protein and biomass and both were found highest at $\mathrm{pH}$ 6.0. Results suggest that there is a correlation between enzymatic activity, total protein and mycelium mass. (Fig.5). The highest amount of total sugar $(2.45 \mathrm{mg} / \mathrm{mL})$ and reducing sugar $(0.88$ $\mathrm{mg} / \mathrm{mL}$ ) were observed at $\mathrm{pH}$ 6.5. Results are presented in (Fig. 6).

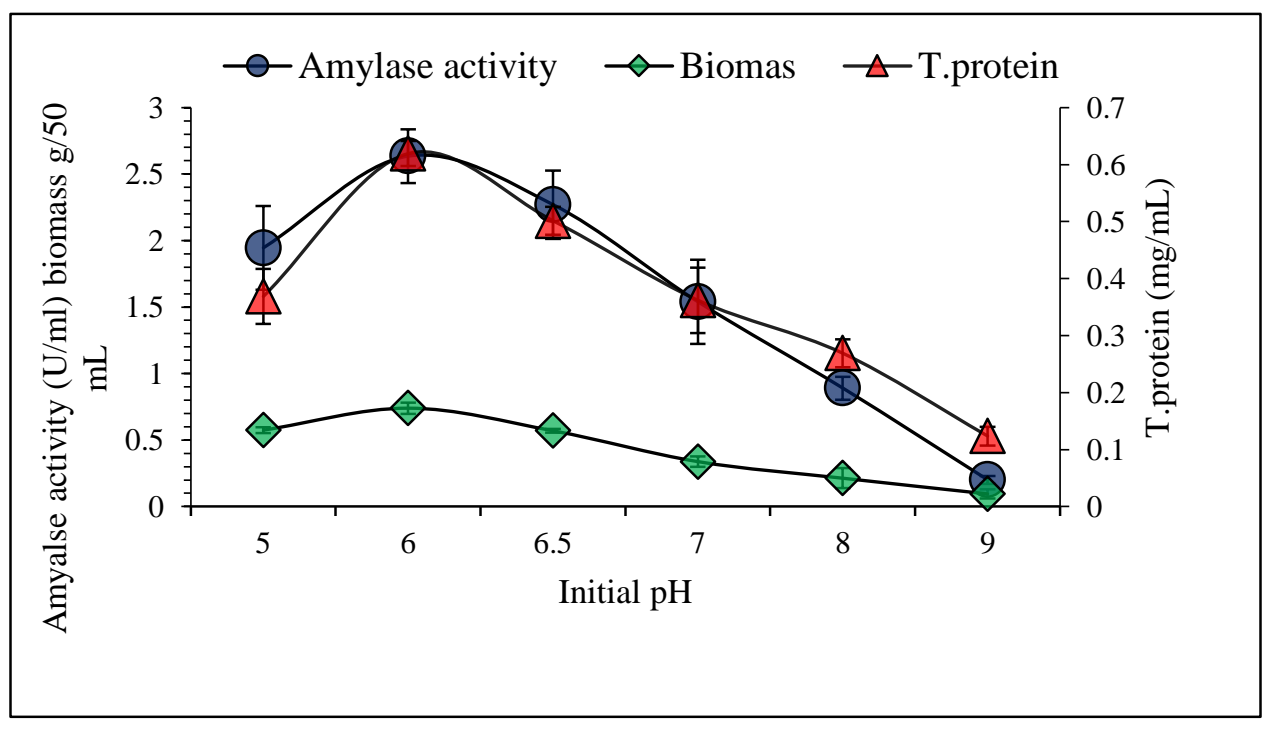

Figure 5. Effect of pH on carbon sources for production of amylase by Aspergillus niger 
Jokhio et al.

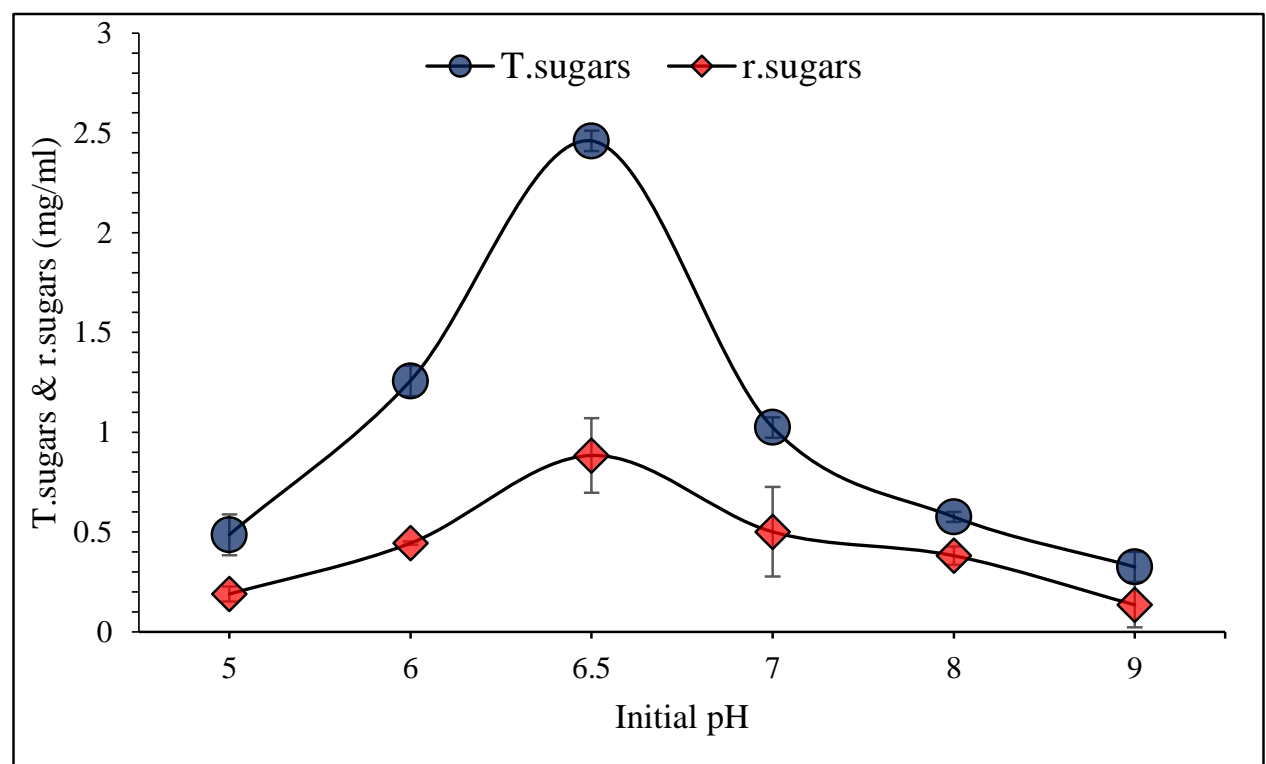

Figure 6. Residual total and reducing sugars from culture broth by Aspergillus niger

Effect of temperature on the production of amylase

Effect of incubation temperature (20 to 60 $\left.{ }^{\circ} \mathrm{C}\right)$ on amylase production and microbial growth were investigated in molasses mineral medium. Amylase concentration increased with the temperature up to $40{ }^{\circ} \mathrm{C}$. Highest enzymatic activity was recorded at
$40{ }^{\circ} \mathrm{C}(2.97 \mathrm{U} / \mathrm{mL})$. On further increase in the incubation temperature decreased the amylase production. Highest total protein content was recorded at $40{ }^{\circ} \mathrm{C}$. Maximal total and reducing sugars were $2.56 \mathrm{mg} / \mathrm{mL}$ and $1.09 \mathrm{mg} / \mathrm{mL}$, respectively at $30{ }^{\circ} \mathrm{C}$. Results are shown in (Fig. 7 \& 8).

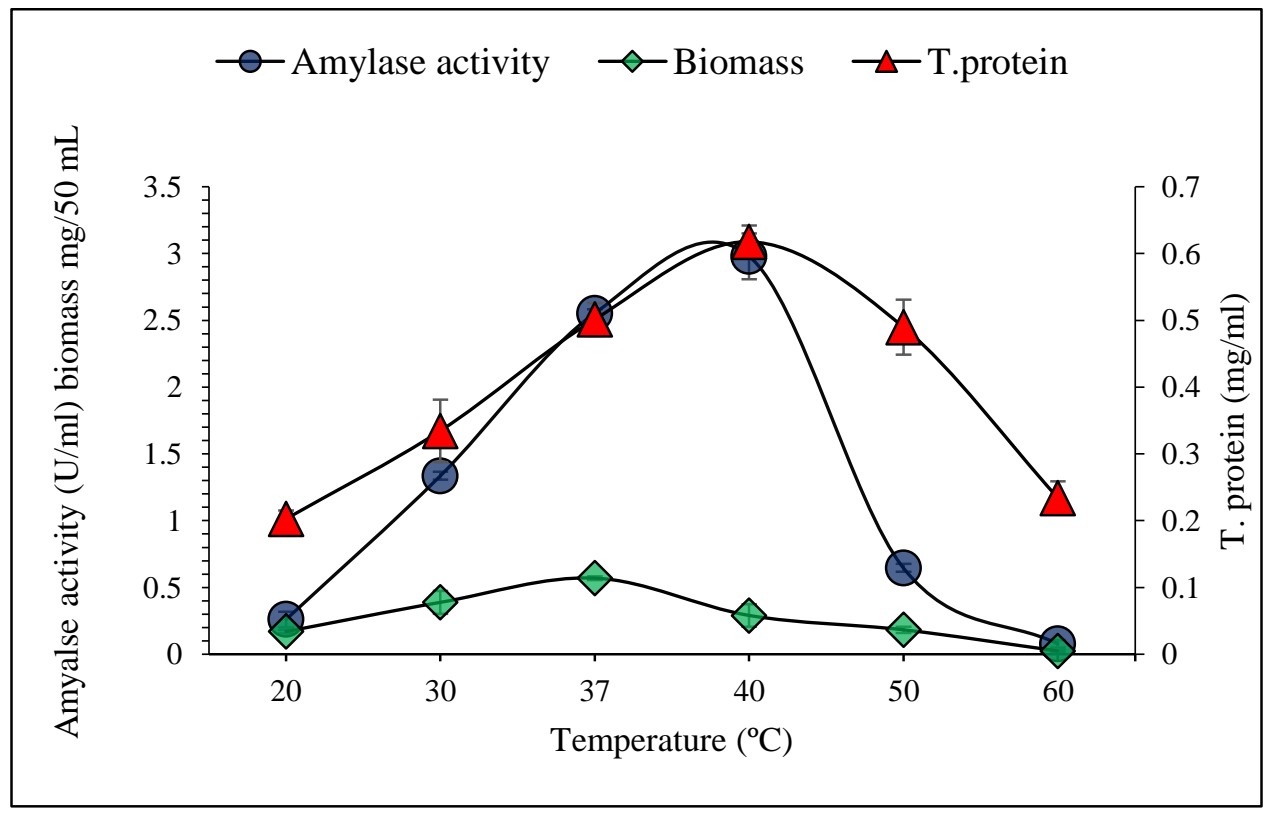

Figure 7. Effect of incubation temperature on the production of amylase by Aspergillus niger 


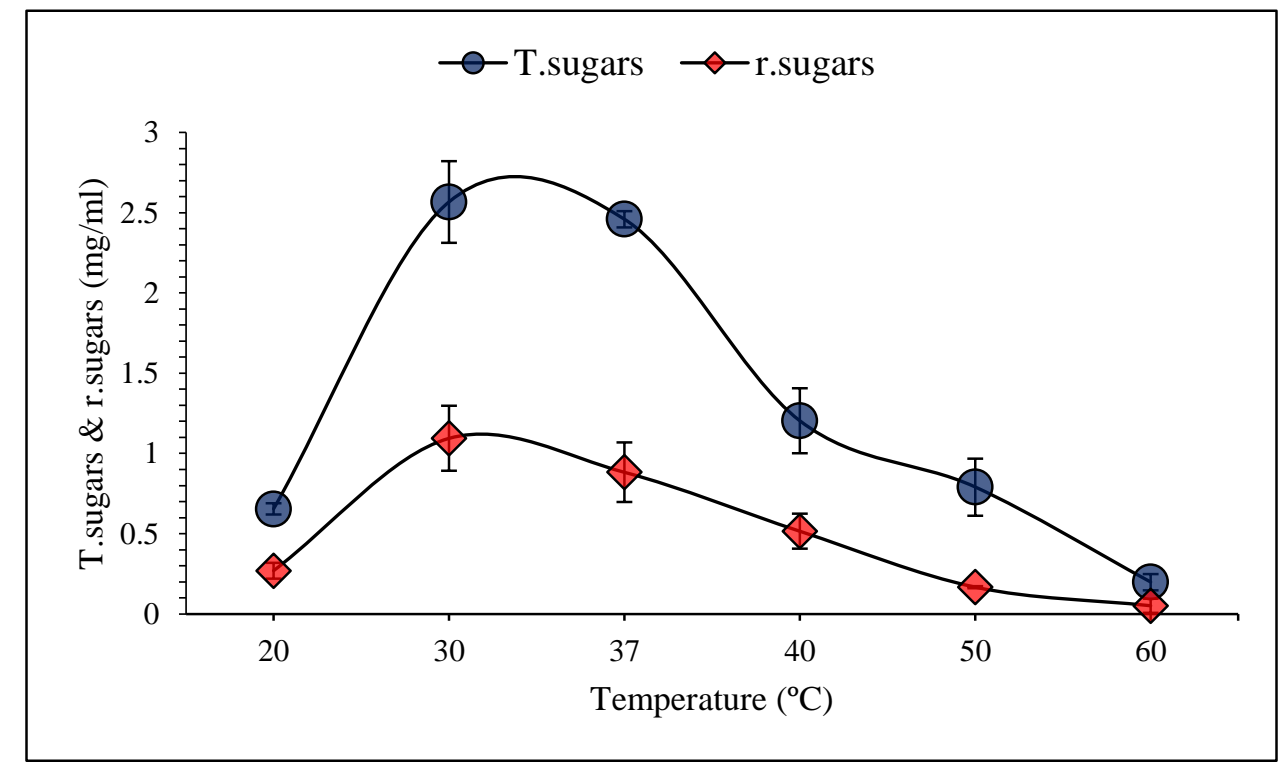

Figure 8. Residual total and reducing sugars from culture broth by Aspergillus niger

\section{Discussion}

Amylase is the $2^{\text {nd }}$ most important hydrolytic enzyme which is used in dishwashing, laundry purpose, paper industry, brewing industry, removing wallpapers and pharmaceuticals [24]. This is why, in present work, amylase production from A. niger strain EFRL-FC-024 was optimized. Agro-industrial waste materials are an excellent source of energy for the production of biofuel, enzymes and other commodity products. Among different low cost agro-industrial waste materials, molasses is a by-product of sugar industry. Molasses enhances microbial growth and enzyme production largely due to its composition. Molasses contains sugars, nitrogen compounds, vitamins and minerals. The optimization of incubation time plays an important role for maximizing enzyme production and microbial growth. In present study, the maximum amount of $\alpha$-amylase was noted at $96 \mathrm{~h}$ of incubation. Esam Ali reported maximum amylase concentration from Aspergillus flavus after 4-5 days of incubation [25]. Highest amylase production from Penicillium fellutanum was noted at $4^{\text {th }}$ day of incubation [26]. Decline in enzyme activity with an increase in fermentation time might be due to denaturation of enzyme or production of other inhibiting secondary metabolites.

Effect of different sugars (molasses, glucose, sucrose, fructose, maltose, galactose and mannitol) was tested on amylase production and microbial growth. Maximum enzyme production was noted when molasses was supplemented in the fermentation medium. This happened probably due to the presence of growth promoters in nutrients rich molasses (nitrogen compounds, vitamins and minerals). Fructose, lactose, sucrose, xylose and glucose additive results in catabolic repression of synthesis of enzymes [27]. Agriculture residues including orange peel, potato peel, corn, wheat and rice as flours have been evaluated as cost-effective carbon sources for amylase production that reduces the fermentation medium cost [28]. Pomegranate peel medium produced maximum amylase concentration [29]. The highest amylase production was obtained from Penicillium rugulosum when grown on starch mineral medium. However, maltose was found the best carbon source for 
amylase production when Bacillus licheniformis was used as amylase producing strain [30].

In enzyme production, $\mathrm{pH}$ plays an important role. In order to determine the effect of initial $\mathrm{pH}$ on microbial growth and amylase production, different initial $\mathrm{pH}$ range (4-9) was used. In our study, maximum amylase production was noted at $\mathrm{pH}$ 6. Similar results were reported for maximum enzyme activity using $A$. niger at $\mathrm{pH} 6.0$ [31]. The $\mathrm{pH} 6.0$ is optimum for amylase production using Aspergillus niger [32]. Sivaramakrishnan et al [33] reported amylase production from Aspergillus oryzae when grown on wheat bran medium and maximal amylase concentration was noted at $\mathrm{pH}$ 5.0. T. maculatum produced highest amylase when grown from $\mathrm{pH} 6.0$ to 7.0. Further increase in the $\mathrm{pH}$ declined amylase production that shows neutrophilic nature of the strain [34].

One of the most important factors for amylase production and microbial growth is temperature. Optimum temperature usually depends on the nature of microorganisms whether strain is thermophilic or mesophilic [35]. In our study, the optimum temperature for amylase activity was $40{ }^{\circ} \mathrm{C}$ and on further increase in temperature declined the amylase activity due to the degradation of enzyme. According to other researchers, maximum amylase production using Aspergillus niger was found at room temperature through submerged and solid state fermentation [36]. Optimum amylase titer was shown from 40 to $50{ }^{\circ} \mathrm{C}$ then decreased [34]. The highest amylase concentration was noted at $30{ }^{\circ} \mathrm{C}$ from Penicillium fellutanum [26]. The optimum temperature for amylase activity at 30, 37 and $40^{\circ} \mathrm{C}$ using Aspergillus spp was reported by Suganthi [37] Ugoh and ljigbade, respectively [38]. Enzymatic activity declines due to protein degradation and change in membrane composition related to high incubation temperature [39].

\section{Conclusion}

In current study, amylase production was optimized using Aspergillus niger strain EFRL-FC-024. Amylase production reached to $2.26 \mathrm{U} / \mathrm{mL}$ after $96 \mathrm{~h}$ of incubation in mineral medium containing glucose as a carbon source. Amylase concentration increased to $2.55 \mathrm{U} / \mathrm{mL}$ when molasses was used in mineral medium. The highest enzyme titer of $2.97 \mathrm{U} / \mathrm{mL}$ was achieved in optimized conditions $(1.0 \% \mathrm{w} / \mathrm{v}$ molasses, $96 \mathrm{~h}, \mathrm{pH} 6.0$ and temperature $40^{\circ} \mathrm{C}$ ). Molasses found a cost-effective industrial waste for amylase production. Amylase produced from this study could be applied in saccharification of starchy material (potato waste) to produce ethanol and other commodity products and can be used in detergent and/ or textile industries.

\section{Authors' contributions}

Performed the experiments, data analysis, results interpretations and manuscript write up: MA Jokhio, Supervised the work and designed the experiments: HA Naqvi, Helped in manuscript write up, editing and review: A Yasmin, Reviewed the manuscript: N Channa, Edited and reviewed manuscript: AS Qureshi, Given technical suggestions: I Khushk.

\section{Acknowledgment}

Institute of Biotechnology and Genetic Engineering (IBGE) University of Sindh, Jamshoro is acknowledged for providing the necessary laboratory facilities.

\section{Reference}

1. Simair AA, Qureshi AS \& Khushk I (2017). Production and Partial Characterization of $\alpha$-Amylase Enzyme from Bacillus sp. BCC 01-50 and Potential Applications. Biomed ResIn article ID, 9173040, 2017: 9.

2. Sindhu R, Binod P, Madhavan A, Beevi US, Mathew AK, Abraham A, Pandey A \& Kumar V (2017). Molecular improvements in microbial $\alpha$-amylases 
for enhanced stability and catalytic efficiency. Bioresour Technol 245: 17401748.

3. Shukla K Singh P, Singh R, Gandhi M, Gramoday C \& Sharma R (2015). Amylases an overview with special reference to alpha amylase. J Glob Biosci 4(1): 1886-1901.

4. Sundarram A \& Murthy TPK (2014). $\alpha$ Amylase Production and their Applications: A Review Ajita. Conf Res Pract Inf Technol Ser 116(4): 77-86.

5. Karam EA, Wahab WAA, Saleh SAA, Hassan ME, Kansoh AL \& Esawy MA (2017). Production immobilization and thermodynamic studies of free and immobilized Aspergillus awamori amylase. Int J Biol Macromol 102: 694703.

6. Kandra L (2003). $\alpha$-Amylases of medical and industrial importance. In: $J$ of $\mathrm{Mol}$ Str: Theo Chem 666: 487-498.

7. Gupta R, Gigras $\mathrm{P}$, Mohapatra H, Goswami VK \& Chauhan B (2003). Microbial $\alpha$-amylases A biotechnological perspective. Process Biochem 38(11): 1599-1616.

8. Pandey A, Nigam P, Soccol CR, Soccol VT, Singh D \& Mohan R (2000). Advances in microbial amylases. Biotechnol Appl Biochem 31(2): 135-152.

9. Souza PMD (2010). Application of microbial $\alpha$-amylase in industry - a review. Brazilian J Microbiol 41(4): 850861.

10. Srivastava R, Shukla K, Singh P, Singh R \& Sharma R (2015). Amylases an overview with special reference to alpha. J Global Biosci 4(1): 1886-1901.

11. Aiyer PV (2004). Amylases and their applications. African J Biotech 4: 15251529.

12. Carlsen $\mathbf{M}$, Spohr AB, Nielsen $\mathbf{J}$ \& Villadsen J (1996). Morphology and physiology of an $\alpha$-amylase producing strain of Aspergillus oryzae during batch cultivations. Biotechnol Bioeng 49(3): 266-276.

13. Ramachandran S (2004). Coconut oil cake a potential raw material for the production of alpha-amylase. Bioresour
Technol 93(2): 169-174.

14. Kumari N, Rani B, Malik K \& Avtar R (2019). Microbial amylases An overview on recent advancement. 7(1): 198-205.

15. Mathew JJ \& Vazhacharickal PJ (2016). Amylase production by Aspergillus niger through submerged fermentation using starchy food byproducts as substrate. Int J Herb Med 4(6): 34-40.

16. Shah I, Gami P, Shukla RM \& Acharya DK (2014). Optimization for $\alpha$-amylase production by Aspergillus oryzae using submerged fermentation technology. Basic Res J Microbiol Basic Res J Microbiol 1(4): 01-10

17. Norouzian, D, Akbarzadeh A, Scharer JM, \& Young M.M (2006). Fungal glucoamylases. Biotechnol Adv 24(1): 80-85.

18. Hashemi M, Mousavi SM, Razavi SH \& Shojaosadati SA (2011). Mathematical modeling of biomass and $\alpha$-amylase production kinetics by Bacillus sp. in solid-state fermentation based on solid dry weight variation. Biochem Eng $J$ 53(2): 159-164-.

19. Qureshi AS \& Dahot MU (2004). Production of Amylase By Fungi Through Submerged Fermentation Pak J Biotechnol 1(1): 35-42.

20. Shafique $\mathrm{S}$, Bajwa $\mathrm{R} \&$ Shafique $\mathrm{S}$ (2009). Screening of Aspergillus niger and A. Flavus strains for extra cellular alpha-amylase activity. Pakistan J Bot 41(2): 897-905.

21. Lowry OH, Rosebrough NJ, Farr Al \& Randall RJ (1951). Protein measurement with the Folin phenol reagent. J Biol Chem 193: 265-275.

22. Montgomery R (1961). Further studies of the phenolsulfuric acid reagent for carbohydrates. Biochim Biophys Acta 48: 591-593.

23. Miller GL (1959). Use of Dinitrosalicylic Acid Reagent for Determination of Reducing Sugar. Anal Chem 31(3): 426428.

24. Tanyildizi MS, Özer D \& Elibol M (2005). Optimization of $\alpha$-amylase production by Bacillus sp. using response surface methodology. Process Biochem 
40(7): 2291-2296

25. Ali EH, El-nagdy MA, Al-garni SM, Ahmed MS \& Rawaa AM (2017). Enhancement of alpha amylase production by Aspergillus flavus AUMC 11685 on mandarin ( Citrus reticulata) peel using submerged fermentation. Eur J Biol Res 7(3): 154-164.

26. Kathiresan K \& Manivannan S (2006). Amylase production by Penicillium fellutanum isolated from mangrove rhizosphere soil. African J Biotechnol 5(10): 829-832.

27. Nandakumar MP, Thakur MS, Raghavarao KSMS \& Ghildyal NP (1999). Studies on catabolite repression in solid state fermentation for biosynthesis of fungal amylases. Lett Appl Microbiol 29(6): 380-384.

28. Ashraf H, Qadeer MA \& Iqbal J. (2005). Pearl millet, a source of alpha amylase production by Bacillus licheniformis. Bioresour Technol 96(10): 1201-1204.

29. Singh S, Singh S, Bali V, Sharma L \& Mangla J (2014). Production of fungal amylases using cheap, readily available agriresidues, for potential application in textile industry. Biomed Res Int : Article ID: 215748 2014: 9.

30. Divakaran D, Chandran A \& Pratap R (2011). Comparative study on production of a-Amylase from Bacillus licheniformis strains. Braz J Microbiol 42(4): 13971404.

31. Shinde RN, Dhangar MJ \& Narwade RB (2014). Amylase Production on Solid State Fermentation by Wild Type and Mutant Bacillus licheniformis \& Aspergillus niger from Agro-wastes. Int $J$ Pharm Sci Res. 5(7): 2703.

32. Saleem A \& Ebrahim MKH (2014). Production of amylase by fungi isolated from legume seeds collected in Almadinah Almunawwarah, Saudi
Arabia. J taibah Univ Sci 8(2): 90-97.

33. Sivaramakrishnan S, Gangadharan D, Nampoothiri KM, Soccol CR \& Pandey A (2006). $\alpha$-Amylases from microbial sources - An overview on recent developments. Food Technol Biotechnol 44(2): 173-184.

34. Bedade D, Deska J, Bankar S, Bejar S \& Singhal R (2018). Fermentative production of extracellular amylase from novel amylase producer, Tuber maculatum mycelium and its characterization. Prep Biochem Biotechnol 48(6): 549-555.

35. Hernández MS, Rodríguez MR, Guerra NP \& Rosés RP (2006). Amylase production by Aspergillus niger in submerged cultivation on two wastes from food industries. J Food Eng 73(1): 93-100.

36. Varalakshmi KN, Kumudini BS \& Nandini BN (2009). Production and characterization of $\alpha$-amylase from Aspergillus niger JGI 24 isolated in Bangalore. Polish J Microbiol 58(1): 2936.

37. Suganthi R, Benazir JF \& Santhi R (2011). Amylase production by Aspergillus niger under solid state fermentation using agroindustrial wastes. Int J Eng Sci Technol 3(2): 1756-1763.

38. Ugoh SC \& Ijigbade B (2013). Production and characterisation of amylase by fungi isolated from soil samples at Gwagwalada. Reports Opin 5(7): 44-53.

39. Kheng PP \& Omar IC (2005). Xylanase production by a local fungal isolate Aspergillus niger USM AI 1 via solid state fermentation using palm kernel cake (PKC) as substrate. Songklanakarin J Sci Technol 27(2): 325-336. 